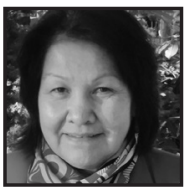

\title{
Collaborative Indigenous Knowledge Research: Acknowledging and Reclaiming Traditional Practices
}

Georgina Martin

\begin{abstract}
This article follows on the heels of the Truth and Reconciliation Commission report to redress the residue of residential schools by enhancing harmony between Indigenous communities and universities. My collaborative community-based Indigenous Knowledge (IK) research attended to the struggle for Secwepemc reclamation, revitalization, and renewal of culture, language, and land. An IK theoretical framework initiated confidence to articulate a Secwepemc worldview within a Eurocentric research context especially while responding to the deeply personal and sensitive topics of cultural identity and language. The aim of knowledge creation is to work from an Indigenous research paradigm through self-location, storytelling, and community relevant protocols.
\end{abstract}

In this article the author expresses how the Truth and Reconciliation Commission of Canada breathes life into a process to redress the residue left by the residential school experience in Canada. In particular, The Truth and Reconciliation Commission of Canada's (2015) Calls to Action legacy on education principle number 10, v., opens doors to "Enabl[e] parental and community responsibility, control, and accountability..." (p. 2). In my role as an Indigenous educator, I seize this opportunity to share my experiences while conducting my community-based doctoral study in my community to demonstrate how harmony can be achieved between an Indigenous community and an academic institution. My identity reclamation study included choosing a research methodology that I could interpret from my respective paradigm as a Secwepemc person. The research is 
based on Wilson's (2008) argument "that using an Indigenous perspective is not sufficient, but that Indigenous research must leave behind dominant paradigms and follow an Indigenous research paradigm" (p. 38). Therefore, I illuminate how my research infused community involvement to support Indigenous identity reclamation and worldviews. It is one example of how Indigenous paradigms can transform research with Indigenous peoples across Canada.

The study further demonstrates how a reciprocal relationship with a Secwepemc Elder and the community of T'exelc sustained a collaborative process to address culturally relevant research. The T'exelc community is one of 17 communities in the Secwepemc nation and is located seven miles south of the City of Williams Lake in the interior of British Columbia. Williams Lake is 547 kilometres north of Vancouver, BC. My research motivation was twofold: I initiated my doctoral research to reclaim my Secwepemc identity as a $\mathrm{PhD}$ researcher through, "Drumming my way home: An intergenerational narrative inquiry about Secwepemc identities." Secondly, I aspired to reciprocate with my community as it is the homeland where I was nurtured. To accomplish this, I needed to bring my Secwepemc ways and sense of belonging into the Western academy. My passion and conviction intensified as critical aspects of identities emerged in relation to the Secwepemc culture and a crucial part of one's "sense of belonging."

The theory of "sense of belonging" emerged from the words of my grandfather, Ned Moiese, who said to "never forget where you come from." I remembered the words while being raised by my grandparents in the T'exelc community and I inherently understood what these words meant for me as a Secwepemc person. It became my impetus to interpret the importance of my grandfather's words. To undertake a holistic approach and one that would benefit the community, I reached out and involved the community in the process. A number of events occurred prior to the study. I spoke with Elder Jean William and kindly asked her to participate in the study as both the Elder participant and Elder advisor. Elder Jean agreed without hesitation, as she too understands the ontological (way of being) importance of living alongside grandparents as she inherited the traditional teachings from her grandparents. The collaborative process began by approaching the T'exelc education department and introducing the concept of identity research. The Education Director recognized the importance of the topic and she proceeded to recruit support from within the community by organizing a community advisory group. The group met in the community and collectively brainstormed ideas and assisted me to identify and frame my research questions. 
While moving through academic space, it was imperative that I maintain and celebrate my Indigeneity. To achieve this, I embraced appropriate theoretical and methodological frameworks that supported my community and respected Elders. Elder Jean guided the transmission of intergenerational cultural knowledge and reinforced the articulation of a Secwepemc worldview. She maintains a very strong connection to her traditional roots transmitted through her grandparents and she honorably carries and shares her wisdom.

For example, when Elder Jean speaks, she acknowledges her homeland and being a member of the Williams Lake Indian Band. She is an Elder and Cultural Advisor who speaks the Secwepemc language fluently and also teaches others. She introduces herself with her Indian name, mumt re nucwenc te nukwstut. As a Secwepemc knowledge keeper, culture and language speaker she carries the responsibility to pass on this knowledge to others who are willing to learn. Her specialty is protecting and sustaining traditional practices. She speaks about the essential connection and continued existence and strength of the Secwepemc people to the land, water, plants, animals, social, cultural, health, and economic effects. All the elements, including our spirituality, affect who we are. It is a living and breathing part of being Secwepemc and sustains the connection to our roots. It is Elder Jean's willingness to support, inspire, and teach that caught my attention. The willing teacher and willing learner came together in a symbiotic and collaborative relationship to fulfill academic research.

\section{Positioning}

My relational intergenerational study began from a position of embodiment alongside Elder Jean and a male youth to explore life histories. Within an Indigenous Knowledge framework, Narrative Inquiry and Indigenous Storywork were logical. Narrative Inquiry facilitated the power of place, of tradition, of passing on traditional ways and recovering them through lived-experiences and the re/telling of storiedlives, while Indigenous Storywork promoted Indigenous Knowledge and challenges the division between Western and Indigenous Knowledges. I positioned my "ways of knowing" and "ways of being" by using my Secwepemc hand drum as my anchor and source of Indigenous Knowledge. My research experience gave me the opportunity to assert who I am in association with my grandparents and my community. I proclaimed that it is imperative for Indigenous scholars to create space within academies to flourish and express their own ways of knowing, rather than succumb to a Western worldview. Indigenous students can more readily privilege their ways 
of knowing with the encouragement of mentors, role models, and committees who promote the advancement of Indigenous Knowledge development. For example, through the support of my supervisory committee, Drs. Jo-ann Archibald, André Mazawi, and Jean Clandinin, and my T'exelc advisory group and community Elder Jean, I was able to incorporate my "ways of knowing" into my study. It required a great deal of strength and courage to engage in such a study due to the pain associated with exploring one's own identity in the context of colonialism and residential school effects. I recommend that students locate and establish relations and relationships that will support their Indigenous Knowledge approaches. It is vital to have champions who strive to understand and grow with you. My champions and advisors helped me transform my articulation and "shift the construction of knowledge to one that does not compromise Indigenous identity and Indigenous principles of independence" (Rigney, p. 119). My ideas were supported and I realized the significance of including my autobiographical narrative along with two other community participants with a focus on intergenerational knowledge transmission, familial relationships, and land-based/culture-based learnings in regards to Secwepemc identities.

In my intergenerational study, I asserted that, "Like many individuals/scholars who have journeyed back to their roots, my journey is personal and vital" (Martin, 2014, p. 5). This statement is relevant because as a Secwepemc scholar, I spoke for myself and I did not speak on behalf of other Indigenous peoples. I shared my story and experiences as it correlated to others stories similar to mine. I respected the diversity of Indigenous peoples with differing cultural locations, therefore not one story or approach will be representative of all, but rather the similarities are definitive. The stimulus of my positioning corresponds with the statement made by Kirkness and Barnhardt (1991) in their pivotal article, "First Nations and higher education: The four R's—respect, relevance, reciprocity, responsibility":

For the First Nations student coming to the university (an institution that is a virtual embodiment of modern consciousness), survival often requires the acquisition and acceptance of a new form of consciousness that not only displaces, but often devalues their indigenous consciousness. (p. 5).

I found this statement extremely troubling and I declined to devalue my Indigeneity in the academy. Rather, I approached my study from my Secwepemc worldview with Elder Jean and the community's support; I spoke from my cultural rootedness, rather than falling into the Western academic pitfall of homogenizing Indigenous experience. In order to achieve balance and accuracy, Elder Jean's guidance was pivotal. In my acknowledgments, 
I express my gratitude to my teacher Elder Jean William for helping me remain grounded in my cultural teachings. I learned so much about the traditional practices of the Secwepemc people through our conversations and you were always there to answer my questions. (Martin, 2014, p. xi)

Her support and understanding definitely contributed to the completion of the cultural-based study.

\section{The Challenges}

\section{The Conscious Battle}

The approach created a dichotomy between Secwepemc and Western worldviews. Hence, I encountered a sense of deficiency and internally, I feared walking into an environment where I felt I did not belong. To counter this feeling, I harnessed the memories and words of my grandfather who always advised me that I am not less than anyone. His voice gave me the strength to legitimate my ideas and approaches, and dispel my feelings of subordination. At the outset, I worked through my own subconscious battle to feel secure about my research topics and direction. I believed, for many Indigenous scholars who prefer to represent their own worldviews, that the process can be painstakingly difficult, more so if the academy is not open to Indigenous content and ideals.

My next challenge was situating and including myself in the study as I inquired into the lives of three Secwepemc people to recognize and reaffirm who we are as a people. I struggled to engage autobiographically because I did not include self in my scholarship prior to the study. By exploring Secwepemc life histories, I countered the denial of history of the Secwepemc people in the vicinity of Williams Lake. Another angle that required careful consideration was respecting propriety and knowledge rights. For example, Elder Jean orally shared information about place names that are considered communal or belonging to certain families. She iterated that the information was for my knowledge only and could not be in print. As an Indigenous scholar, I understand the requirements of adhering to community protocols in terms of information that can be shared publicly, while some is for community use only. 


\section{The Journey}

A good part of the journey was establishing how to interact with and represent the community and the academy. My Indigenous methodology reminded me of the importance of balance: "heart, mind, body and spirit" (Archibald, 2008). In 2011, I wrote, "I believe that this PhD journey with the hand drum in one hand will lead me back to important cultural values. The hand drum signifies the heart, honesty in my work and overall integrity to treat people with respect" (Martin, 2011, p. 112). This statement is important because it is necessary to include "heart, honesty, and respect" in the research affiliated with an Indigenous community. For many Indigenous scholars, this is where the difference lies; I am confident that Indigenous scholars are more likely to enter the academy with their families, communities, and collectivity in hand. Given the context of the study and the union of land, language, and culture, it was essential to have Elder Jean contribute to Indigenous Knowledge from land-based and culture-based perspectives. In personal communication with Elder Jean William on February 10, 2011, she stated, "you are not Secwepemc unless you return to the land." Secwepemculecw further explains how the Secwepemc are connected to the land: [Secwep]—unfolding/spreading out and coming home; [emc]-people of; $[u l e c w]$ - the land of, place of, territory. During the journey together with Elder Jean, I learned to combine academic wisdom with the wisdom of Elders' teachings, especially connection to land and the stories that are told. Elder Jean was taught traditional ways by her grandparents, and she practices and passes on the teachings to others. When Elder Jean speaks, she begins by proclaiming that she has a passion for stories and connection to the land. She thanks the land for everything that the land has given her. She shares her knowledge and wisdom from orality, not the written academic text. She asks, "What is storytelling?" And she responds by saying, the Secwepemc did not have written or recorded records. What she shared is what she knows as the Secwepemc way of life. The purpose of oral history and its value is how the information was passed on about the Secwepemc culture, values, beliefs, and our way of life through storytelling (telling stories). Storytelling is deeply rooted in our language and land. The family stories help the listener learn about the way of life of the Secwepemc people. Oral traditions were used to record and pass on information to future generations about our history. These might include records of specific events (i.e., birth, death, marriages, adoptions). The stories kept the culture alive, which is a strong component of our survival. Each time a listener heard a story, he or she learned something about the beliefs, values, culture, and ways of life practiced by the Secwepemc people. Important ways of teaching and learning infused values in a reflective way of transmitting customs and culture. We as Indigenous 
peoples are naturally active listeners. I was privileged to be gifted with these stories. Elder Jean described her great respect for her grandmother (kyé7e) and the ways she was always willing to share stories. From these lessons, she learned about the importance of the land and the connection to the culture. She said, "I was raised by our true Elders; they were connected to the land." The land and its components are living and breathing parts of the Secwepemc people and they sustain the connection to our roots. My positioning and the conscious battle explains my preparedness for Wilson's (2008), Research is Ceremony. I was required to conceptually and concurrently adhere to community protocols and the university's research ethics during the study. This is a portrayal of how Kirkness and Barnhardt's four Rs guided my research. The four $\mathrm{R}$ principles supported cultural protocols that are essential when conducting research with Indigenous peoples. During the study, mutual respect ensued between the researcher and the community and the mandate of the project; I demonstrated the relevance of what the study could offer to the community for future development; I practiced reciprocity by taking some information and giving some back; and I managed my responsibility by working safely to respect ethical boundaries by protecting my research accountability to myself, the community, and the academy. The rigor of Indigenous research will vary according to the researcher and his or her community.

\section{Indigenous Storywork and Narrative Inquiry}

\section{Tools of Reclamation and Renewal}

By slowly and deliberately using Indigenous Storywork and Narrative Inquiry, I began to mend my broken-hearted longing and sense of injustice which supported self-transformation. As described, "I found among my study participants that Secwepemc identities are rooted in the culture. Culture can be practiced or observed; I suggest that one's identity comes from the heart" (Martin, 2014, p. 184). Understanding oneself is definitely a heart process. I learned by listening to others carefully and I applied the gift of research to heal through stories of others, but also to commit to their meaning through practice. Self-actualization, reclamation, and renewal are keys to Indigenous research and Indigenous Storywork and Narrative Inquiry provided the vessel to allow me to traverse the waters of cultural identity in safe, relational, and embodied spaces. 
By exploring three generations of Secwepemc lived-experiences that are shaped by social, cultural, familial, genealogical, and kinship ties, it helped me and others understand the importance of life histories. The approach applied is extremely important and meaningful for Indigenous students in an academic institution because many of us continue to feel marginalized. In order to carefully reclaim space, it required the application of methodologies that supported the embodied and relational aspects of the study which is found in both Indigenous Storywork and Narrative Inquiry.

Both methodologies assisted in the rendering of the participant stories while intersecting and merging through a narrative process. Firstly, I found affinity with Narrative Inquiry because it presented an avenue to support my engagement with lived-experience stories. I shared events that could elicit painful memories, therefore it was necessary to invoke an approach that would allow me to release personal stories that would not inflict emotional and spiritual harm or overwhelming discomfort on anyone in the study. Secondly, Indigenous Storywork represented the Indigenous meaning behind the representation of stories and the necessary protocols that support the telling of these stories. The differences lie within the interpretation. According to Clandinin and Connelly (2000) Narrative Inquiry guides the telling and retelling of lives lived while Archibald's (2008) Indigenous Storywork creates space for the orator and the listener to make meaning about the shared stories. The point of resonance within Narrative Inquiry and Indigenous Storywork is their relational qualities. They are similar and different. Narrative Inquiry supported my stories, while Indigenous Storywork sanctioned the telling of the participants' stories. The purpose of these two methodologies was to establish a technique that extended respect and integrity for the storytellers to tell their truth. Narrative Inquiry has an analytical element, while Indigenous Storywork compels the storytellers to make meaning of the stories without evaluation from the teller. The twofold function was to channel the stories in the most legitimate fashion for each of the participants to have ownership of the retold stories about their lives. In each instance with the study participants, their narratives were written and affirmed with them to ensure the context represented their words and views. Through back and forth consultation and approval of each segment, the shared stories came through their voice. Archibald (2008) explains that retelling and reconstructing stories is not a straightforward matter, rather it is important to keep the power-the "spirit" (p. 147) of the story alive. While Clandinin and Connelly (2000) affirm lived experience"that is, lives and how they are lived" (p. xxii). I began to feel comfort in telling my own story to make meaning of identities. 


\section{Summary}

Through positionality and embodiment, the three participants brought who they are into the Western system. Bouvier (Ward \& Bouvier, 2001) explains that,

[t] he notion of positionality is intimately connected with how we construct identities in the culture and subcultures in which we live...So long as identity is viewed as static or is essentialized, I will never be able to reconcile who I am. (p. 188)

By storying and restorying our lives through dual narrative processes, we remained true to who we are as Indigenous peoples, which is central to our dignity. This is an example of reconciliation as we continue to create space for Indigeneity in the academy. It is a difficult process and challenge to open up our lives within a structure that has not been accepting. All three participants recognized that in doing so, we are contributing to a healing process as we expose insights about our lives to reclaim and retain our cultural identities. The healing will continue with the children and grandchildren as they learn the language, stories, and cultural practices.

\section{References}

Archibald, J. (2008). Indigenous storywork: Educating the heart, mind, body, and spirit. Vancouver, BC: UBC Press.

Clandinin, D. J., \& Connelly, F. M. (2000). Narrative inquiry: Experience and story in qualitative research. San Francisco: Jossey-Bass.

Kirkness, V., \& Barnhardt, R. (1991). First Nations and higher education: The four R's - respect, relevance, reciprocity, responsibility. Journal of American Indian Education, 30(3), 1-15.

Martin, G. (2011). Drumming my way home: A Secwepemc perspective. The Canadian Journal of Native Studies, 31(2), 107-116.

Martin, G. (2014). Drumming my way home: An intergenerational narrative inquiry about Secwepemc identities. (Unpublished doctoral dissertation). University of British Columbia, Vancouver, B.C.
Rigney, L. (1999). Internationalization of an Indigenous anticolonial cultural critique or research methodologies: A guide to Indigenist research methodology and its principles. Wicazo Sa Review, 14(2), 109-121.

Truth and Reconciliation Commission of Canada (TRC). (2015). Truth and Reconciliation Commission of Canada: Calls to action. Winnipeg, MB: Author.

Ward, A., \& Bouvier, R. (2001). Resting lightly on Mother Earth: The Aboriginal experience in urban educational settings. Calgary, $A B$ : Detselig Enterprises Ltd.

Wilson, S. (2008). Research is ceremony: Indigenous research methods. Black Point, NS: Fernwood Publishing. 


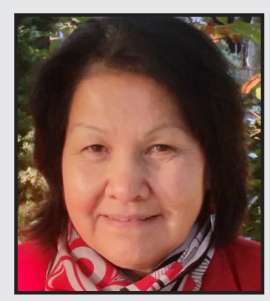

Georgina Martin is Secwepemc. She was raised in the T'exelc community and is also a member of Lake Babine Nation. She obtained her PhD at the University of British Columbia. She has 23 years of professional experience within various federal government departments in the development of programs for the improvement of health, social welfare, employment, and education for Aboriginal peoples. Her research interests are Indigenous self-determination, Indigenous education, and Indigenous voice. As a mature Aboriginal woman, she combines her academic training with her lived and professional experiences to advance a decolonizing agenda that protects and revitalizes Indigenous Knowledges and relationships around the world. 